\title{
Allergy to Red Meat: A Diagnosis Made by the Patient and Confirmed by an Assay for IgE Antibodies Specific for Alpha-1,3-Galactose
}

\author{
Mamadou Kaloga $^{a}$ Sarah Kourouma ${ }^{a}$ Yao Isidore Kouassi ${ }^{a}$ \\ Elidje Joseph Ecra ${ }^{a} \quad$ Ildevert Patrice Gbery ${ }^{a}$ Ange S. Allou ${ }^{a}$ \\ Almamy Diabate ${ }^{b}$ Djokouehi Djeha ${ }^{a}$ Abdoulaye Sangaré $^{a}$ \\ Yao Pauline Yoboue ${ }^{a}$ \\ ${ }^{a}$ Department of Dermatology and Infectiology, School of Medicine, \\ Félix Houphouët-Boigny University, BP V166, Abidjan, and ${ }^{b}$ Department of Dermatology, \\ Alassane Ouattara University, Bouaké, Ivory Coast
}

\section{Key Words}

Allergy $\cdot$ Red meat $\cdot$ Africa

\begin{abstract}
We report the first case of allergy to red meat observed in Ivory Coast. A 49-year-old male presented with pruritus. The diagnosis of allergy to red meat was confirmed by an assay for IgE antibodies specific for alpha-1,3 galactose. Interestingly, the disease was considered a spell to the patient who was suspected of being a sorcerer by the community.
\end{abstract}

\section{Introduction}

Allergic reactions to food of animal origin (milk and eggs) are known and common. Allergy to meat used to be considered unusual, but many cases have now been identified in America [1, 2] and Australia [3] and some cases in European countries such as Germany, France and Switzerland [4, 5]. Allergy to meat results from hypersensitivity to hydrocarbon antigen alpha galactose 1-3 [6]. In Africa, and particularly in Ivory Coast, allergies to milk and eggs are often called totems. Red meat has not previously been identified as being re-

\section{KARGER}

Prof. Mamadou Kaloga, MD

Department of Dermatology and Infectiology, School of Medicine

Felix Houphouët-Boigny University

14BP1960, Abidjan 14 (Ivory Coast)

E-Mailkaloganas@yahoo.fr 
Kaloga et al.: Allergy to Red Meat: A Diagnosis Made by the Patient and Confirmed by an Assay for IgE Antibodies Specific for Alpha-1,3-Galactose

sponsible for allergy so far. We report the first case of an allergy to red meat observed in our country.

\section{Case Report}

A 49-year-old male cultivator residing in Mankono (western Ivory Coast) with no particular history presented with pruritus. For 3 years, he had had recurrent episodes of abdominal pain, followed by pruritic papules on the body $3 \mathrm{~h}$ after meals. The patient tried herbal medicines with a regression of lesions within $2 \mathrm{~h}$. He believed that a spell had been cast, comforting his option for traditional medicines. However, 2 years later, he found that the symptoms appeared only after the consumption of red meat such as beef, mutton and agouti. He therefore stopped eating red meat. After 15 days, the patient restarted his red meat consumption, and the same symptoms reappeared. He decided not to consume red meat for several months and had no symptoms. After 4 months, he consumed smoked meat and had no symptoms for the first 2 months, but then the symptoms recurred. He stopped the consumption of red meat and limited his meat intake to poultry and fish, with no reaction after consumption. The notion of tick bite was not found, but the patient reported being bitten repeatedly by insects. He had no domestic animal such as dog or a cat and did not report consuming cat meat. Suspected of being a sorcerer and upset by this situation, he joined his brother who decided to bring him to the capital for medical care. We performed a red meat challenge with beef in our department. Three hours later, the patient complained from abdominal pain, followed by pruritic papules on the body (fig. 1) without anaphylaxis. After prescription of antihistamines, the symptoms disappeared within hours. The blood count was normal. Beef patch-tests were negative. Skin prick tests were not performed because the patient refused. We recommended continuing the diet without red meat. Having learned about the IgE antibodies specific for alpha-1,3-galactose (alpha-gal)at a meeting 6 months later, we asked the patient to come to our department to be tested. He first refused, but after 1 day of negotiation with the help of his brother, he accepted the determination of $\mathrm{IgE}$ antibodies specific for alpha-gal. The assay was done in a national laboratory in France, and the expenses were paid by us. Specific IgE to alpha-gal was $11.10 \mathrm{kU} / \mathrm{l}$ (normal value: $<2$ ). Relieved by the positivity of this test and by the explanations given, the patient went home.

\section{Discussion}

Meat ingestion can cause a reaction delayed by several hours because of the delayed release of IgE alpha-gal during the digestion process. The discovery of specific IgE antibodies to alpha-gal as a good marker of allergy to foods such as meat from mammals was made by Commins et al. [7]. Before this discovery, it was difficult to give a rational explanation to patients.

The diagnosis of meat allergy is based on the presence of clinical signs after ingesting meat. In our case, the link to meat ingestion was suspected by the patient. Food challenge tests reproduced the symptoms, contributing to the clinical diagnosis of allergy. Tick bites have been reported by many authors in case of allergy to red meat [8, 9]. A single tick bite could make a person vegetarian or at least force him to give up red meat. IgE antibodies to alpha-gal have also been found in patients allergic to cats and in those with parasitic infection in Africa [10].We reported an uncommon case of allergy to meat whose diagnosis was 
Kaloga et al.: Allergy to Red Meat: A Diagnosis Made by the Patient and Confirmed by an Assay for IgE Antibodies Specific for Alpha-1,3-Galactose

made by the patient himself, facilitating the allergological investigations necessary to confirm the diagnosis. The assay for specific alpha-gal IgE antibodies was a very significant contribution that helped reassuring the patient and discouraging the idea of a spell. The exclusion of red meat has been continued, and no further crisis has been observed in our patient.

\section{Conclusion}

Unjustified beliefs and poverty in our population are often the cause of late consultations. Many of our patients receive traditional herbal therapy before coming to the hospital. The disease becomes a spell, and only rational explanations, as in this case, can relieve some patients.

\section{Statement of Ethics}

The patient gave his informed consent.

\section{Disclosure Statement}

There is no conflict of interest to declare.

\section{References}

1 Steinke JW, Platts-Mills TAE, Commins SP: The alpha-gal story: lessons learned from connecting the dots. J Allergy Clin Immunol 2015;135:589-596.

2 Plats-Mills TAE, Schuyler AJ, Tripathi A, et al: Anaphylaxis to the carbohydrate side chain alpha-gal. Immunol Allergy Clin North Am 2015;35:247-260.

-3 Van Nunen SA, O'Connor KS, Clarke LR, et al: An association between tick bite reactions and red meat allergy in humans. Med J Aust 2009;190:510-511.

4 Biedermann T, Röcken M: Delayed appearance of symptoms in immediate hypersensitivity: type I sensitization to galactose- $\alpha$-1,3-galactose (in German). Hautarzt 2012;63(suppl 1):76-79.

-5 Morisset M, Richard C, Astier C, et al: Anaphylaxis to pork kidney is related to IgE antibodies specific for galactose-alpha-1,3-galactose. Allergy 2012;67:699-704.

6 Bircher AJ, Scherer Hofmeier K, Michel S: Die Entdeckung eines neuen Allergens: die Galactose 1,3-alphaGalactose. Schweiz Med Forum 2013;13:19-21.

7 Commins S, Satinover S, Hosen J, Mozena J, Borish L, Lewis B: Delayed anaphylaxis, angioedema, or urticaria after consumption of red meat in patients with IgE antibodies specific for galactose-alpha-1,3-galactose. J Allergy Clin Immunol 2009;123:426-433.

8 Commins SP, James HR, Kelly LA, et al: The relevance of tick bites to the production of IgE antibodies to the mammalian oligosaccharide galactose-alpha-1,3 galactose. J Allergy Clin Immunol 2011;127:1286-1293.

-9 Hamsten C, Starkhammar M, Tran TAT, et al: Identification of galactose-1,3-galactose in the gastrointestinal tract of the tick Ixodes ricinus; possible relationship with red meat allergy. Allergy 2013;68:549-552.

10 Arkestål K, Sibanda E, Thors C, Troye-Blomberg M, Mduluza T, Valenta R, Grönlund H, van Hage M: Impaired allergy diagnostics among parasite-infected patients caused by IgE antibodies to the carbohydrate epitope galactose- $\alpha$ 1,3-galactose. J Allergy Clin Immunol 2011;127:1024-1028. 
Case Reports in
Dermatology

Case Rep Dermatol 2016;8:10-13

DOI: $10.1159 / 000443631$

(C) 2016 The Author(s). Published by S. Karger AG, Basel www.karger.com/cde

Kaloga et al.: Allergy to Red Meat: A Diagnosis Made by the Patient and Confirmed by an Assay for IgE Antibodies Specific for Alpha-1,3-Galactose

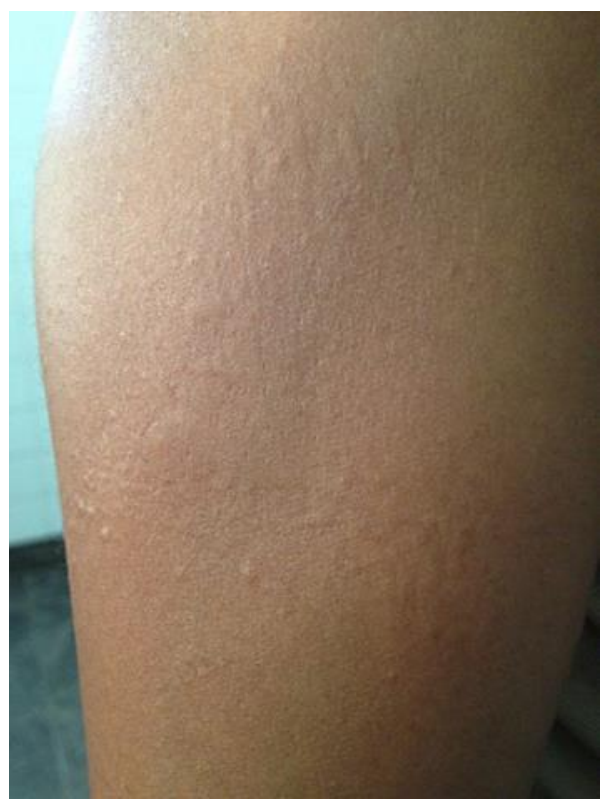

Fig. 1. Pruritic papules on the elbow of the patient. 